\title{
PERGESERAN LETAK PERMAKAMAN BELANDA DI KOTA SURABAYA DARI ABAD 18 HINGGA AWAL ABAD 20
}

\section{DUTCH CEMETERY DISPLACEMENT IN SURABAYA FROM 18 CENTURY UNTIL EARLY 20 CENTURY}

\author{
Lengkong Sanggar Ginaris \\ Pascasarjana Arkeologi Universitas Gadjah Mada, Indonesia \\ lengkong.sanggar.g@ugm.ac.id
}

\begin{abstract}
One of the remains of the colonial period in Indonesia is the Dutch cemetery. The Dutch cemetery have splendid tombs, western-style decorations and gravestone written in Dutch. Dutch cemeteries can be find in cities such as Surabaya. During colonial period, Surabaya had four Dutch cemeteries in Jembatan Merah, Krembangan, Peneleh and Kembang Kuning. The aim of this study is to determine factors behind the displacement of the Dutch cemetery in Surabaya. The data in this study are including not only historical data (maps of Surabaya in 1787, 1825, 1866, and 1934), but also archives. The remaining observable cemeteries are in Peneleh and Kembang Kuning, because the Dutch cemeteries at Jembatan Merah and Krembangan have been demolished. Data from the observation are then sorted and analyzed to determine the displacement pattern and the factors behind them. The results show that there have been three Dutch cemetery displacements in Surabaya, triggered by three factors: health, unstable ground condition, and land conversion into settlement.
\end{abstract}

Keywords: Cemetery; urban landscape; colonial; Surabaya

\section{ABSTRAK}

Salah satu tinggalan masa kolonial di Indonesia adalah permakaman Belanda. Permakaman Belanda ditandai keberadaan makam yang megah, hiasan bergaya barat serta batu nisan yang menggunakan bahasa Belanda dalam huruf Latin. Permakaman Belanda dapat ditemukan pada kota-kota yang pernah diduduki Belanda seperti Surabaya yang diduduki Belanda dari tahun 1743 hingga 1942. Selama dikuasai Belanda, Surabaya pernah memiliki empat permakaman Belanda seperti di Jembatan Merah, Krembangan, Peneleh, dan Kembang Kuning. Penelitian ini bertujuan mengetahui faktor yang melatarbelakangi bergesernya permakaman Belanda di Surabaya. Data yang digunakan antara lain sejarah (peta kota Surabaya tahun 1787, 1825, 1866, dan 1934) dan arsip-arsip. Data arkeologi yang masih tersisa dan dapat diamati adalah permakaman Belanda di Peneleh dan Kembang Kuning karena permakaman Belanda di Jembatan Merah dan Krembangan sudah dibongkar sejak lama. Data dipilah dan dianalisis untuk mengetahui pola pergeseran letak permakaman Belanda di Surabaya dan faktor-faktor yang memicu pergeseran tersebut. Hasil penelitian menunjukkan sudah terjadi tiga kali pergeseran permakaman Belanda di Surabaya, yang dipicu oleh tiga faktor: kesehatan, tanah yang tidak stabil, dan alih fungsi lahan sekitar permakaman.

Kata Kunci : Permakaman; lanskap budaya; kolonial; Surabaya

Artikel Masuk

Artikel Diterima
: 18-03-2019

: 21-10-2019 


\section{PENDAHULUAN}

Permakaman adalah rangkaian kegiatan yang dimulai dari menggali, menempatkan mayat ke dalam liang, menimbun kembali dan memberi tanda atau simbol di atasnya agar dikenal umum (Nurhadi, 1987, hlm. 2). Tujuan dari adanya permakaman adalah sebagai tempat untuk merawat mayat sekaligus untuk mencegah terjadinya wabah penyakit yang ditimbulkan dari mayat yang membusuk. Bila dimasukkan ke dalam konteks lanskap, permakaman merupakan salah satu bentuk lanskap budaya yang dihasilkan dari pengolahan bentang lahan oleh suatu kelompok manusia secara aktif dan berkembang mengikuti dinamika manusia (Anshcuetz, Wilshusen, Sheick, 2001, hlm. 191). Menurut Francaviglia (1971), permakaman adalah bentuk ekspresi visual dan spasial orang-orang yang masih hidup terhadap kematian. Sebagai lanskap budaya yang berkembang mengikuti dinamika manusia, permakaman senantiasa mengalami perubahan spasial atau aristektur makam yang ada di dalamnya. Permakaman tak hanya melayani tujuan fungsional sebagai tempat memakamkan jenasah saja, namun juga sebagai jembatan penghubung antara orang yang masih hidup dengan orang yang sudah meninggal, bentuk ungkapan manusia pada keabadian, dan sarana pengingat kematian. Karakteristik permakaman dapat dilihat secara individual dengan melihat batu nisan setiap individu atau secara kolektif dengan melihat pengaturan tata ruang dan penempatannya dalam lingkungan permukiman (Francaviglia, 1971).

Tradisi permakaman di Indonesia sudah ada sejak zaman prasejarah dengan dibuktikan adanya temuan kubur-kubur batu. Tradisi permakaman lalu menghilang pada masa Hindu-Buddha dan kemudian muncul kembali saat kedatangan Islam. Makam-makam dari era Islam ditandai dengan jirat, batu nisan, dan cungkup (Ambary, 1998, hlm. 146). Kedatangan bangsa lain seperti bangsa Tionghoa dan bangsa Eropa menambah ragam jenis makam di Indonesia. Ketika orang Tionghoa meninggal, mereka dimakamkan di tempat yang disebut bong. Lokasi bong biasanya ditempatkan di lereng bukit atau dekat tempat berair. Bentuk bong dapat dikenali dari bentuknya seperti tempurung kura-kura dan dilengkapi dengan altar dewa bumi di sampingnya (Shanti, 2010, hlm. 67). Sementara orang-orang Belanda yang meninggal dimakamkan di suatu kompleks permakaman yang disebut kerkhof.

Keberadaan kerkhof ditandai dengan makam-makam yang memiliki bentuk dan bahasa prasasti yang berbeda dengan makam Tionghoa dan makam pribumi. Makam Belanda terkesan lebih megah serta memiliki hiasan yang lebih kaya bila dibandingkan makam pribumi. Bahasa yang dipakai pada batu nisan kebanyakan adalah bahasa Belanda dan ditulis dalam huruf Latin. Hiasan pada kerkhof umumnya bergaya barat seperti malaikat dan karangan bunga. Kata kerkhof berasal dari Bahasa Belanda yang berarti halaman gereja. Hal tersebut merujuk pada kebiasaan permakaman di Eropa sebelum abad ke 19, dimana orang-orang Eropa memakamkan jenasah di halaman gereja. Pemilihan halaman gereja sebagai tempat permakaman didasarkan atas aspek religi, dimana orang Eropa percaya bahwa halaman gereja merupakan tempat yang suci. Kebiasaan dari Eropa tersebut kemudian dibawa oleh orang Belanda pada masa kolonial. Permakaman menjadi kebutuhan yang penting bagi orang Belanda di Nusantara 
karena banyak orang Belanda yang meninggal akibat kondisi tubuh yang belum mampu beradaptasi dengan iklim tropis (Mytum; 1989, hlm. 286).

Seiring dengan pertumbuhan jumlah penduduk di Eropa pada abad ke-18, kota-kota semakin padat dan gereja kehabisan lahan untuk permakaman. Akibatnya, jasad yang baru saja meninggal biasanya akan dikubur di atas jasad lama. Lama-kelamaan, jarak antara permukaan tanah dengan jasad menjadi semakin dangkal. Jasad-jasad yang membusuk akhirnya menginfeksi orangorang yang masih hidup sehingga timbul wabah di kota-kota besar. Perubahan besar pengelolaan dan desain permakaman terjadi di Perancis. Pada tahun 1776, pemerintah dan pengurus gereja di Perancis secara resmi melarang penguburan di halaman gereja dan mengharuskan permakaman untuk dibuka di tempat lain. Kebijakan tersebut kemudian ditiru oleh negeri Eropa lain (Mytum, 1989, hlm. 289).

A. Poldevaart dalam majalah Locale Techniek edisi Oktober 1933, menjelaskan bahwa tidak semua tempat bisa dipakai untuk lokasi permakaman. Ada beberapa kriteria yang harus dipenuhi antara lain, air harus dapat merembes ke tanah, jenis tanahnya bukan tanah lempung atau padas, dan drainasenya bagus. Selain itu, lingkungan sekitar sebisa mungkin dalam keadaan kosong sehingga permakaman tersebut nantinya dapat diperluas. Letak permakaman sebisa mungkin tidak menghambat perluasan kota. Selain itu, lokasi makam juga jangan terlalu dekat dengan permukiman, karena orang tidak senang tinggal di dekat permakaman. Pemilihan lokasi makam juga harus mempertimbangkan kedekatan jarak dengan permukiman agar rombongan pengantar jenasah tidak berjalan terlampau jauh sehingga mereka tidak kelelahan ketika tiba di permakaman.

Salah satu kota yang memiliki permakaman Belanda adalah Surabaya. Berdasarkan peta tahun 1825, 1866, dan 1930, kota Surabaya pernah memiliki tiga permakaman Belanda. Permakaman Belanda pada peta tersebut ditandai dengan simbol palang $(+)$. Letak permakaman Belanda berdasarkan peta tahun 1825 berada di Krembangan, sementara berdasarkan peta tahun 1866, letak permakaman Belanda hanya berada di Peneleh. Kemudian berdasarkan peta tahun 1930, selain permakaman Belanda yang ada di Peneleh, terdapat permakaman lain dibuka di Kembang Kuning. Permakaman Krembangan pada masa sekarang sudah tidak ditemukan bekasnya selain toponim jalan Kuburan Lama. Dengan demikian, permakaman Belanda yang masih tersisa di Surabaya adalah permakaman Belanda di Peneleh yang sudah tidak dipakai untuk kegiatan permakaman dan permakaman Belanda Kembang Kuning yang sampai sekarang masih digunakan untuk kegiatan permakaman untuk orang Kristen.

Penelitian permakaman Belanda pernah dilakukan oleh Balai Arkeologi Yogyakarta pada tahun 1998-1999 dengan judul "Keletakan dan Permakaman Belanda pada Kota-kota Pantai". Hasil penelitian menyimpulkan bahwa keletakan kompleks makam Belanda selalu berada di daerah pinggiran kota yang jauh dari permukiman penduduk kota. Dari segi bentuk makam, setiap makam memiliki variasi bentuk yang berbeda tergantung dari status sosial yang melatarbelakangi dari orang yang dimakamkan. Penelitian permakaman Belanda lainnya yang melihat pada aspek bentuk dilakukan oleh Ade Faizal Tantomi (2013) dengan judul "Bentuk-Bentuk Nisan Belanda di Kerkhof Purworejo" dan Cahya Ratna Mahendrani (2013) dengan judul “Nisan Makam Belanda Peneleh 
Surabaya; Kajian Tentang Bentuk dan Ragam Hias". Penelitian Tantomi menyimpulkan bahwa di Kerkhof Purworejo terdapat empat bentuk makam, yakni makam berbentuk peti mati, monumen, bangunan gereja, dan lempengan batu. Sementara itu, penelitian Mahendrani menyimpulkan bahwa makam Belanda di Peneleh memiliki sembilan tipe ragam hias, yakni flora, fauna, malaikat, simbol Kristen, tanda jasa, bintang, insrkripsi, arsitektural, dan kelompok lain. Masing-masing ragam hias nisan memiliki makna simbolis tertentu sesuai dengan konteks permakaman. Penelitian lain terkait permakaman Belanda dilakukan oleh Suratminto (2008) dengan judul "Makna Sosio-Historis Batu Nisan VOC di Batavia". Melalui data inskripsi dan ikon pada batu nisan makam Belanda, Suratminto melakukan rekonstruksi struktur sosial dan budaya komunitas VOC di Batavia. Sementara itu, belum ada penelitian yang meneliti tentang faktor perpindahan suatu permakaman dari satu tempat ke tempat lainnya. Berdasarkan hal tersebut, permasalahan yang dibahas pada tulisan ini yakni faktor apa yang mendasari bergesernya makam Belanda di Surabaya pada kurun waktu 1743-1916?

\section{METODE}

Penelitian ini menggunakan metode bersifat deskriptif dengan penalaran induktif. Penalaran induktif adalah metode yang dimaksudkan untuk menjelaskan masalah dengan data yang ada. Tujuan dari penalaran ini adalah untuk memperdalam pengetahuan mengenai suatu gejala tertentu atau mendapatkan pengetahuan baru mengenai gejala tersebut. Pendekatan yang dipakai pada penelitian ini adalah dengan menggunakan pendekatan lanskap. Menurut Branton (2009), pendekatan lanskap memakai hubungan spasial seperti perbedaan akses pada sumberdaya, visibilitas, jarak atau kedekatan dengan tempat lain, dan kualtias lingkungan. Proses pengumpulan data merupakan proses pertama yang dilakukan. Data yang digunakan dalam penelitian ini terdiri dari data sejarah dan data arkeologi. Data sejarah yang dimaksud adalah peta kota Surabaya pada tahun 1787, 1825, 1866, dan 1934 dan literatur yang dapat memberikan keterangan tentang kedua permakaman tersebut seperti buku Oud Soerabaia dan Niew Soerabaia yang keduanya ditulis oleh Von Faber. Sementara itu, data arkeologi yang masih tersisa dan dapat diamati adalah permakaman Belanda di Peneleh dan Kembang Kuning, sementara permakaman Belanda yang ada di Jembatan Merah dan Krembangan tidak ditemukan data arkeologi berupa makam karena sudah dibongkar sejak lama. Data-data tersebut kemudian dipilah dan selanjutnya dianalisis untuk mengetahui pola pergeseran letak permakaman Belanda di Surabaya dan faktor-faktor yang memicu pergeseran tersebut. 


\section{HASIL PENELITIAN}

\section{Lokasi dan Lingkungan}

Kota Surabaya secara astromonis di 07o 12' - 07-21' Lintang Selatan dan $112^{\circ} 36^{\prime}-112^{0} 54^{\prime}$ Bujur Timur. Luas wilayah kota Surabaya adalah $33.306,30$ km². Surabaya terletak di pesisir utara Jawa Timur. Batas wilayah kota Surabaya antara lain sebelah utara dengan Laut Jawa, sebelah timur dengan Selat Madura, sebelah selatan dengan Kabupaten Sidoarjo dan sebelah barat dengan Kabupaten Gresik. Secara geografis tanah di kota Surabaya merupakan dataran rendah dengan ketinggian 0-10 meter di atas permukaan laut. Berdasarkan Staatsblad no. 479 tanggal 1 April 1906, Surabaya ditetapkan sebagai kota praja. Pada masa sekarang, Surabaya merupakan ibukota dari provinsi Jawa Timur. Sebagian besar wilayah Surabaya adalah dataran rendah dengan ketinggian $3-8 \mathrm{~m}$ di atas permukaan laut. Struktur tanahnya adalah tanah alluvial yang merupaan hasil endapan tiga sungai yang melewati Surabaya, yakni sungai Kali Mas, Kali Surabaya, dan Kali Wonokromo.

\section{Sejarah Kota Surabaya}

Surabaya pada tahun 1250 merupakan kota pelabuhan bernama Glagah Arum. Pada tahun 1270, Raja Kertanegara dari Kerajajaan Singosari menghancurkan Glagah Arum dan di tempat tersebut didirikan kota pelabuhan baru bernama Hujung Galuh. Pada 1292, tentara Kubilai Khan tiba di Jawa Timur untuk menghukum raja Kertanegara karena sudah menghina utusan Kubilai Khan yang memaksa Singosari tunduk kepada Kubilai Khan. Namun Kertanegara sudah terbunuh pada saat tentara Mongol tiba. Menantu Kertanegara, Raden Wijaya, memanfaatkan tentara Mongol tersebut untuk merebut tahta dan kemudian Raden Wijaya berbalik menyerang tentara Mongol. Raden Wijaya berhasil mengalahkan tentara Mongol pada 31 Mei 1293 dan tanggal tersebut ditetapkan sebagai hari jadi kota Surabaya. Pada abad ke-14 dan ke-15, Surabaya merupakan bagian dari Kerjaaan Majapahit dan menjadi tempat transit pedagang. Pada masa periode kerajaan Islam, pelabuhan Surabaya kalah penting dibanding Tuban dan Gresik. Orang-orang Portugis kemudian tiba di Surabaya pada 1521 dan kemudian diikuti oleh orang Belanda baru pada 1612. Orang Belanda lalu membuka pos dagang di Surabaya pada 1617. Pada 1625, kota Surabaya yang saat itu merupakan kerajaan berdaulat diduduki oleh Sultan Agung. VOC lalu menutup rumah dagangnya di Surabaya pada 1628 dan baru kembali pada 1646. Sampai 1743, kota Surabaya berada di bawah kekuasaan pangeran yang diangkat oleh Kerajaan Mataram atas persetujuan VOC. Setelah terjadi pemberontakan Tionghoa pada 1740-1743, Surabaya berada di bawah kendali VOC sepenuhnya. Pada 1746, VOC membangun benteng Belvedere. Secara ekonomis, peran Surabaya tidak terlalu besar karena produk ekspornya hanyalah beras. Surabaya mulai berkembang setelah wilayah ujung timur Pulau Jawa dikuasai VOC dan Surabaya menjadi pelabuhan ekspor untuk hasil bumi seperti nila, kopi, dan tebu. Dalam perkembangannya, VOC mendirikan beragam fasilitas untuk memenuhi kebutuhan manusia yang tinggal di kota 
seperti rumah tinggal, gereja, rumah tinggal, kantor, kanal, tembok kota, dan gudang (Leushuis, 2014, hlm. 236-237).

Pada masa pemerintahan Daendels, kedudukan Surabaya diperkuat tak hanya sebagai pos dagang Belanda saja, namun juga sebagai pusat pemerintahan, militer, dan perdagangan Belanda di Jawa Timur. Tembok kota dan benteng Belvedre lalu dirobohkan. Kemudian dibangun sarana-sarana pendukung lain seperti galangan kapal, penjara, bengkel militer, rumah residen, kantor pos, gedung pengadilan. Surabaya sebagai kota pelabuhan semakin berkembang dengan diterapkannya kebijakan cultuurstelsel. Pada masa Gubernur Jenderal J. van den Bosch, dibangun kanal, pematang, bastion, dan tembok yang mengitari permukiman Eropa, Cina, Moor, dan Arab. Dampak dari pembangunan sarana pertahanan tersebut adalah tergusurnya kota pribumi lama yang berada di sebelah selatan kota dan penduduk pribumi pindah ke kampungkampung sebelah selatan di pinggiran Kali Mas seperti Peneleh, Genteng, dan Bubutan (Gambar 1). Penggusuran pusat pemerintahan pribumi oleh pemerintah kolonial menyebabkan komponen kota tradisional Jawa seperti alun-alun, masjid di sebelah barat, dan kediaman bupati tidak bisa ditemukan lagi di Surabaya. Melalui UU Agraria yang disahkan pada 1870, perekonomian di Hindia-Belanda terbuka untuk orang atau perusahan swasta. Sejak saat itu, Surabaya berkembang pesat sebagai kota dagang. Berbagai usaha seperti bank, asuransi, dan perusahaan dagang milik orang Eropa dibuka. Ramainya kegiatan perdagangan dan jasa di Surabaya berdampak pada peningkatan jumlah penduduk Surabaya. Sensus yang dilakukan pemerintah kolonial pada tahun

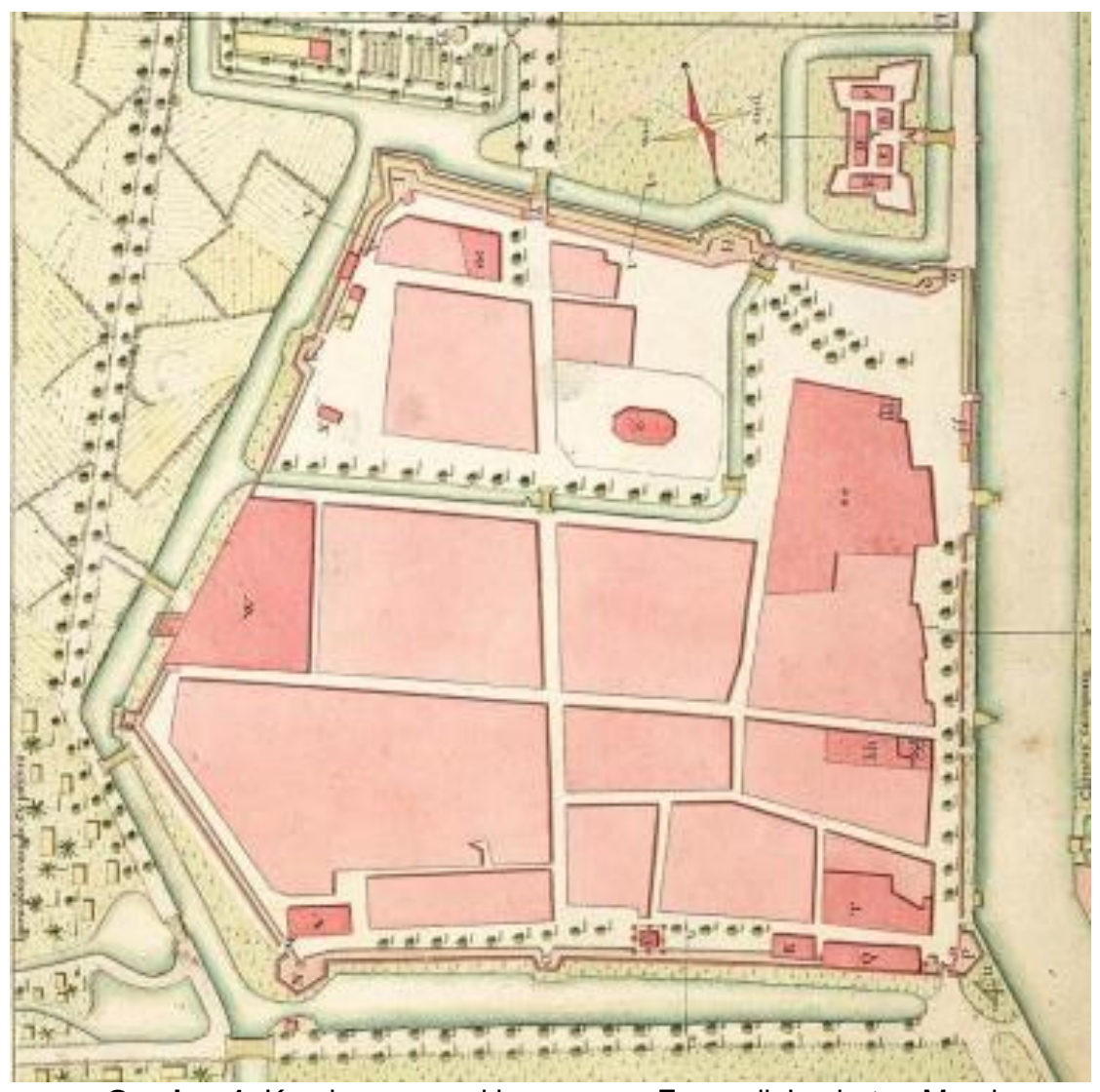

Gambar 1. Keadaan permukiman orang Eropa di Jembatan Merah,

Surabaya pada peta tahun 1787. Permukiman tersebut berada di sisi barat Jembatan Merah.

(Sumber: maps.library.leiden.edu) 
1815 menunjukan penduduk Surabaya berjumlah 154.512 jiwa dengan komposisi orang Eropa 307 orang, orang Tionghoa 4.203 jiwa, orang Timur Asing lain 441 jiwa, dan penduduk pribumi 24.547 jiwa. Sementara sensus terakhir yang dilakukan pemerintah kolonial pada 1930 nenunjukan jumlah penduduk Surabaya meningkat menjadi 336.614 orang dengan komposisi 26.463 orang Eropa, 36.797 orang Tionghoa, 5.682 orang Timur Asing, dan 265.872 orang pribumi. Untuk mendukung pembangunan kota Surabaya, maka dibentuklah pemerintah kotapraja Surabaya pada tahun 1906 (Widodo, 2002, hlm. 406).

\section{Permakaman Belanda Pertama di Surabaya}

Permakaman Belanda pertama di Surabaya berada di halaman gereja yang dulu pernah berdiri di Willemsplein. Gereja tersebut dibangun oleh Abraham Christoffel Coertz pada 1759. Sebagaimana tradisi permakaman di Eropa, orang-orang Belanda di Surabaya juga memakamkan jenasah di halaman gereja (kerkhof) karena saat bagi orang Belanda dan Eropa lain, gereja adalah titik fokus yang penting dalam kehidupan masyarakat mengingat segala kegiatan penting dilakukan di sini seperti upacara pembaptisan bayi, pernikahan, dan kematian. Selain itu, halaman gereja juga dipandang sebagai tempat suci (Kerrigan, 2017, hlm. 141). Kendati orang tidak lagi menggunakan halaman gereja sebagai tempat permakaman, namun istilah kerkhof masih dipakai untuk menyebut permakaman Belanda walau letaknya tidak lagi di halaman gereja dan lebih populer dibanding begrafplaats yang merupakan sebutan resmi untuk permakaman dalam bahasa Belanda. Pada tahun 1929, gereja tersebut dibongkar untuk dibangun sebagai kantor Internationale Handels-, Credit, Veereniging Rotterdam. Sementara itu, batu nisan yang berada di sekitar gereja sudah dipindah ke tempat lain sebelum gereja tersebut dibongkar. Salah satu yang dipindah adalah batu nisan Abraham Christoffel Coertz yang dipindah ke GPIB Bubutan sebelum tahun 1929 (Gambar 2).
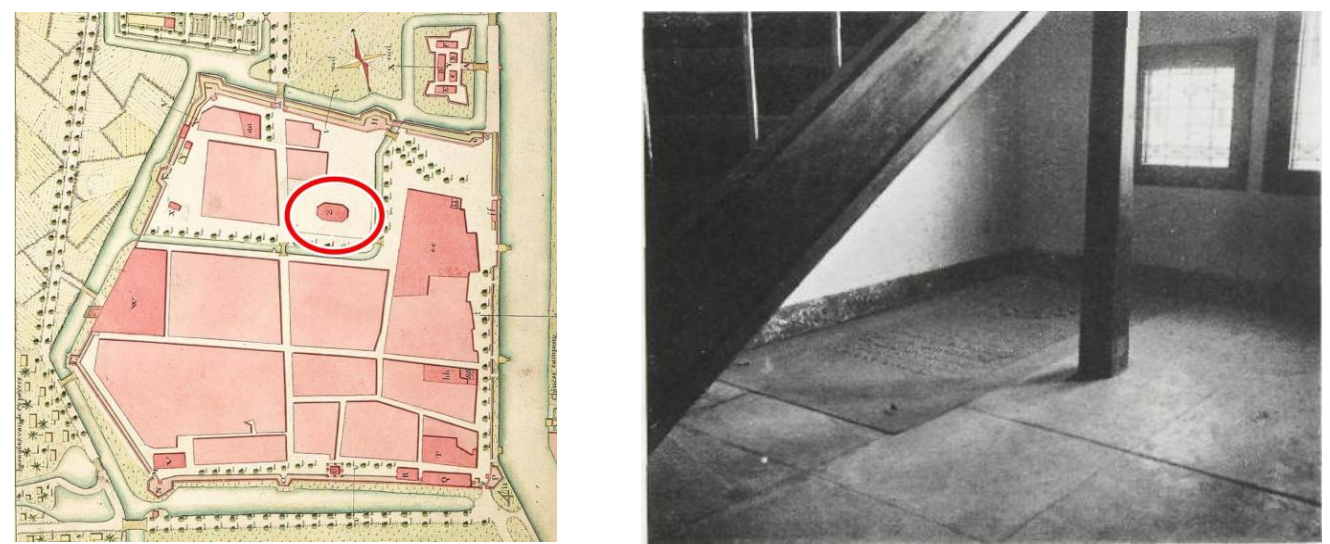

Gambar 2. Letak gereja pertama di Surabaya yang berada di dalam tembok kota Surabaya (kiri) dan Batu nisan A. Ch. Coertz yang dipindah dari Gereja Jembatan Merah ke Gereja Bubutan (kanan). (Sumber: maps.library.leiden.edu dan Oud Soerabaia)

\section{Permakaman Belanda Krembangan}

Setelah permakaman di sekitar gereja dilarang pada 25 Januari 1793, pemerintah kolonial membuka permakaman Belanda di Krembangan yang 
waktu itu berada di pinggir barat kota (Gambar 3). Sayangnya karena di sekitar Krembangan merupakan tanah rawa yang sering tergenang air sehingga permakaman Krembangan dirasa tidak sesuai lagi untuk permakaman. Ketika lahan permakaman di Krembangan hampir terisi penuh, Dewan Gereja meminta pemerintah Surabaya untuk membuka lahan permakaman baru. Pada tahun 1925, pemerintah kota menggusur permakaman Belanda Krembangan. Makammakam beserta batu nisannya kemudian dipindah ke Kembang Kuning dan karena itu tidak ada yang tersia dari permakaman Belanda di Krembangan. Satunya-satunya petunjuk bahwa di Krembangan pernah terdapat permakaman selain peta adalah toponim jalan "Oude Kerkhofweg" atau kini menjadi Jalan Kuburan Lama.

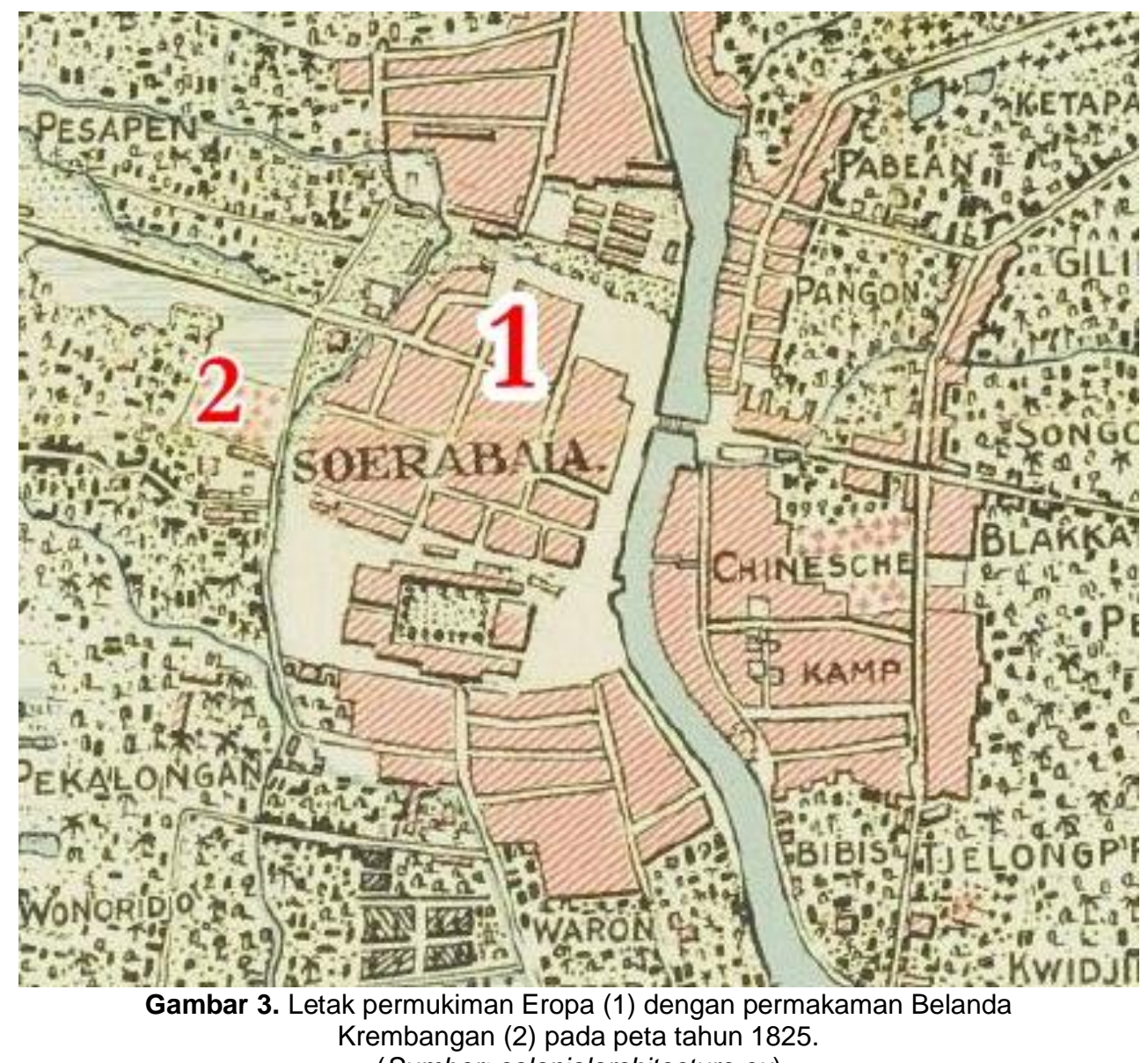

(Sumber: colonialarchitecture.eu)

\section{Permakaman Belanda Peneleh}

Permakaman Belanda Peneleh merupakan permakaman Belanda tertua yang masih tersisa di Surabaya. Permakaman Peneleh terletak di Jalan Makam Peneleh, Kelurahan Peneleh, Kecamatan Genteng, Surabaya. Permakaman Belanda di Peneleh sudah tidak dipakai lagi untuk kegiatan permakaman Sejarah permakaman Belanda Peneleh dimulai ketika permakaman Belanda Peneleh sudah tidak layak untuk permakaman. Pemerintah kolonial kemudian memilih 
sepetak lahan di Kampung Peneleh yang berada di sebelah selatan sebagai tempat permakaman baru. Pembukaan lahan tersebut menghabiskan biaya sebanyak 10.000 gulden. Lokasi tersebut dipilih karena letaknya dianggap tidak terlalu mengganggu perluasan permukiman Eropa yang berada di sebelah barat Kali Mas. Berdasarkan peta tahun 1866, kampung Peneleh saat itu masih belum padat bangunan hunian dan lahan di sekitar permakaman Peneleh masih berupa kebun bambu (Gambar 4). Pembukaan lahan makam tersebut berada di bawah pengawasan insinyur Geil (Von Faber, 1932, hlm. 314-315). Pada Agustus 1847, lahan permakaman selesai dibuka dan 1 Desember di tahun yang sama, diadakan upacara peresmian. Permakaman Belanda Peneleh merupakan lahan permakaman untuk orang-orang Eropa, Yahudi, orang pribumi dan Tionghoa yang menganut agama Kristen dan Katolik. Baru satu tahun dibuka, sudah ada lebih dari seratus jasad yang dimakamkan di Peneleh. Pada 1915, diperkirakan sudah ada 13.000 jenazah yang dimakamkan di sana. Sementara itu, peningkatan jumlah penduduk memiliki dampak terhadap peningkatan kebutuhan akan tempat tinggal sehingga tanah di sekitar permakaman Peneleh yang tadinya kosong berubah menjadi perkampungan (Gambar 4). Karena sudah terkepung oleh permukiman pribumi, maka permakaman Peneleh akhrinya tidak bisa diperluas.
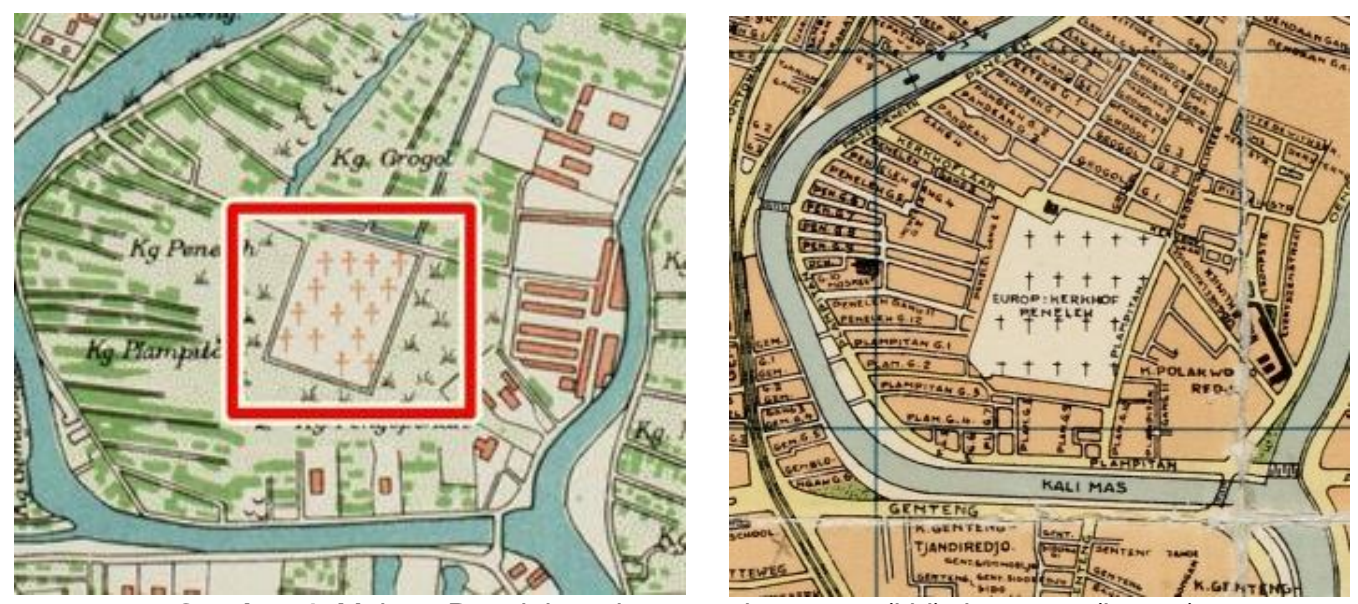

Gambar 4. Makam Peneleh pada peta tahun 1866 (kiri) dan 1934 (kanan). (Sumber: colonialarchitecture.eu)

Permakaman Belanda Peneleh menggunakan konsep Garden Cemetery yang diperkenalkan di Eropa pada masa Revolusi Industri (Gambar 5). Konsep Garden Cemetery terlihat pada makam-makam monumental dan dilengkapi dengan ragam hias seperti malaikat, salib, dan kolom. Di samping itu, makammakam yang ada di Peneleh ditata dengan mengikuti pola grid. Munculnya gerakan Garden Cemetery dipicu oleh pertumbuhan kaum urban, peningkatan jumlah kelas menengah, dan tingginya angka kematian yang terjadi selama Revolusi Industri (Muller, 2015, hlm. 16). Gerakan garden cemetery mengubah kesan muram sebuah permakaman dengan menata permakaman serapi mungkin dan makam yang ada dibuat seperti monumen. Permakaman tersebut pun harus layak dari segi kesehatan, yakni letaknya harus berada di pinggiran sehingga tanah di sekitarnya tidak dicemari oleh jasad yang terdekomposisi. 

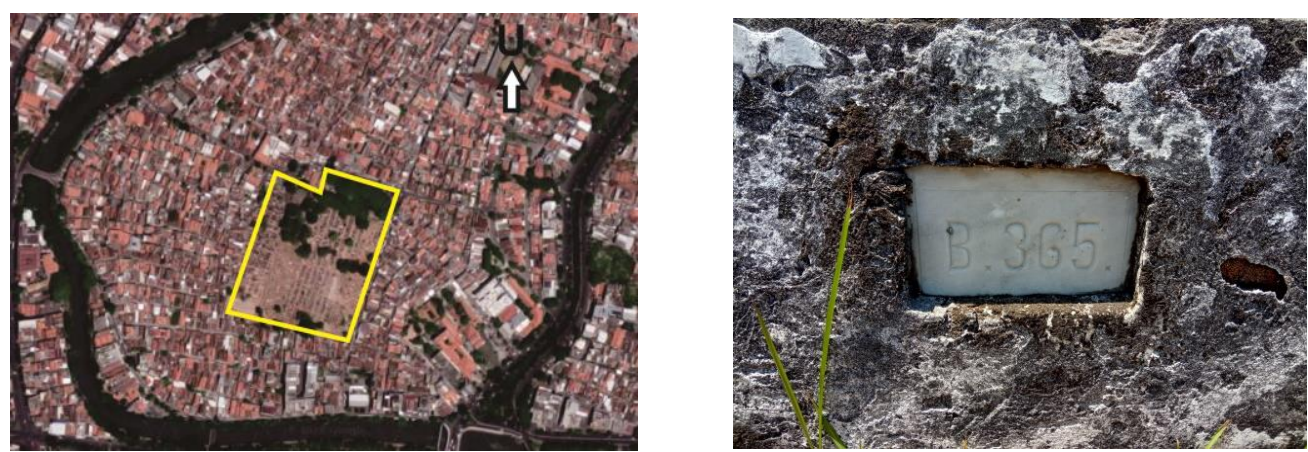

Gambar 5. Keadaan Makam Peneleh pada tahun 2019 (kiri) dan kode makam (kanan).

(Sumber: maps.google.com dan Dokumentasi Pribadi)

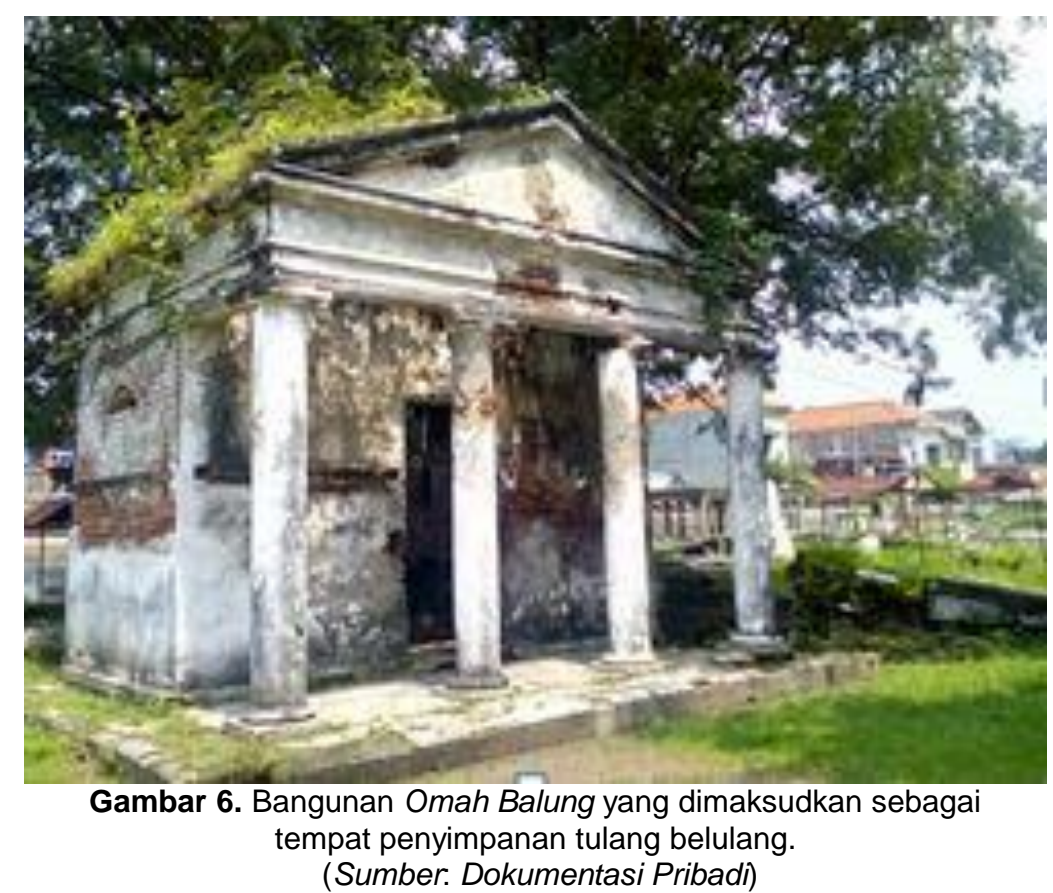

Masing-masing makam di permakaman Belanda Peneleh diberi kode berupa huruf dan angka(Gambar 5). Huruf tersebut merupakan kode jenis penguburan yang dibagi menjadi tiga, yakni huruf $B, E$, dan $C B$. Huruf $B$ merupakan tanda untuk makam yang menggunakan penguburan jenis grafkelder yaitu penguburan dengan ruang di bawah tanah. Penguburan ini dibuat dengan melapisi lubang kubur yang memiliki kedalaman 2 meter dengan susunan bata dan dilapisi semen. Hal tersebut bertujuan agar kedap air. Huruf E mewakili penguburan jenis Aarden graven, yakni penguburan dilakukan langsung dipendam dengan tanah tanpa membuat ruangan terlebih dahulu seperti penguburan huurkelder. Kemudian huruf CB menandai penguburan jenis huurkelders. Penguburan ini mirip dengan jenis grafkelder, hanya saja ruang di bawah tanah dapat disewakan untuk orang lain. Di permakaman Belanda Peneleh, terdapat bangunan ossuarium (Gambar 6), yakni bangunan yang 
difungsikan sebagai tempat penyimpanan tulang dan karena itu masyarakat setempat menyebutnya sebagai omah balung.

\section{Permakaman Belanda Kembang Kuning}

Sekitar awal abad 20, pemerintah kolonial kembali menggeser letak permakaman Belanda. Kali ini di dekat wilayah Darmo yang merupakan kawasan permukiman baru di barat Kali Mas. Pemakaman Belanda tersebut kini berada di Jalan Kembang Kuning, Kelurahan Pakis, Kecamatan Tegalsari, Surabaya. Permakaman Peneleh berada di tengah perkampungan. Jika melihat peta tahun 1934, letak permakaman Peneleh sudah dikelilingi dengan permukiman yang dihuni oleh orang pribumi. Selain menjadi tempat permakaman umum, permakaman Kembang Kuning juga menjadi ereveld atau tempat pemakaman tentara Belanda yang gugur sewaktu Perang Dunia Kedua dan Perang Kemerdekaan. Sejarah pembukaan kerkhof Kembang Kuning berkaitan dengan mulai penuhnya permakaman Belanda di Peneleh. Untuk memenuhi kebutuhan permakaman yang semakin mendesak, pemerintah kota Surabaya memutuskan untuk membuka permakaman baru di tempat lain. Pada awalnya permakaman baru tersebut akan dibuka di daerah Gubeng yang tanahnya sudah dibeli pemerintah kota pada 1909. Namun karena tempatnya sering tergenang banjir dan drainasenya buruk, maka tempat tersebut tidak jadi dipilih. Akhirnya lokasi permakaman baru jatuh di daerah Kembang Kuning, di sebelah barat kawasan permukiman Eropa yang baru di Darmo (Gambar 7).

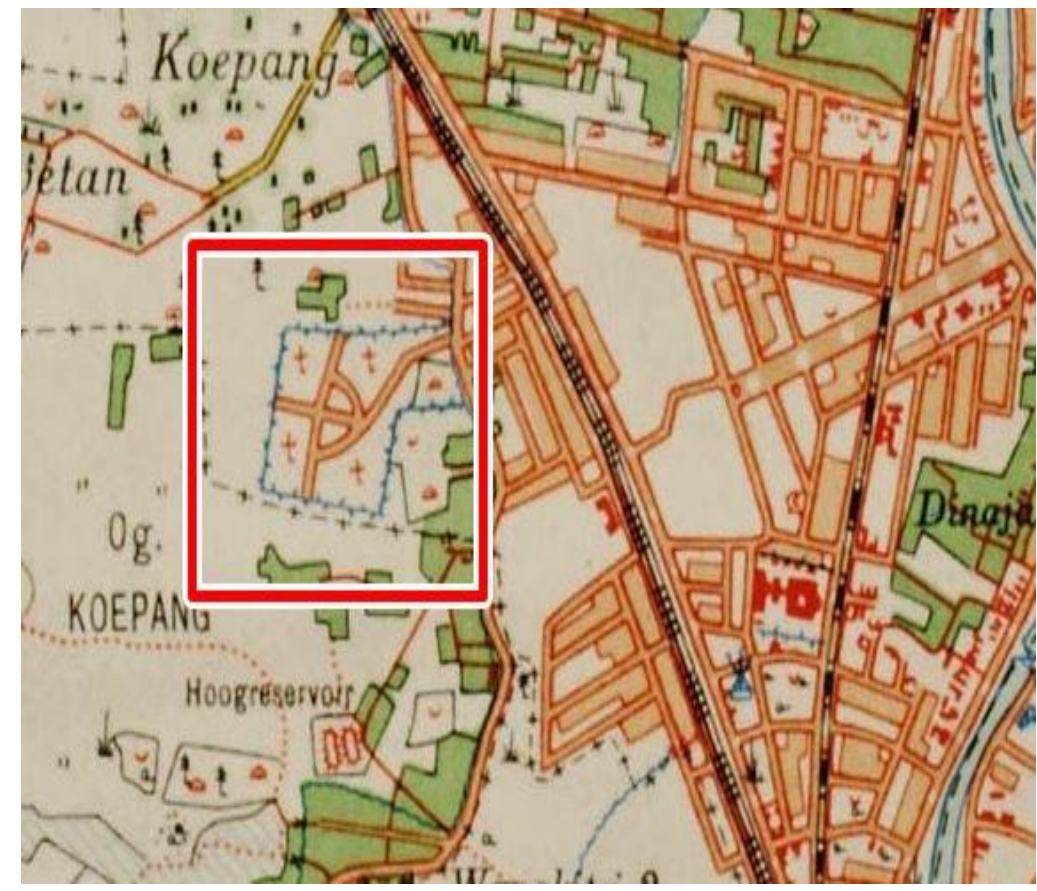

Gambar 7. Makam Kembang Kuning pada peta tahun 1934 (Sumber: maps.library.leiden.edu).

Pada 1916, kompleks permakaman ini dibuka untuk umum. Berbeda dengan permakaman Peneleh, permakaman Kembang Kuning dipecah menjadi 
beberapa bagian sesuai dengan latar belakang jenazah, yakni bagian Protestan, Katolik, Yahudi, dan mereka yang tidak diketahui agamanya. Permakaman Kembang Kuning kemudian menyediakan bagian baru bagi anak-anak dan orang yang meninggal karena bunuh diri. Lahan di sebelah selatan permakaman Kembang Kuning kemudian dibeli oleh pemerintah kota yang nantinya akan dijadikan sebagai lahan tambahan permakaman Kembang Kuning (Von Faber, 1934, hlm. 186-187).
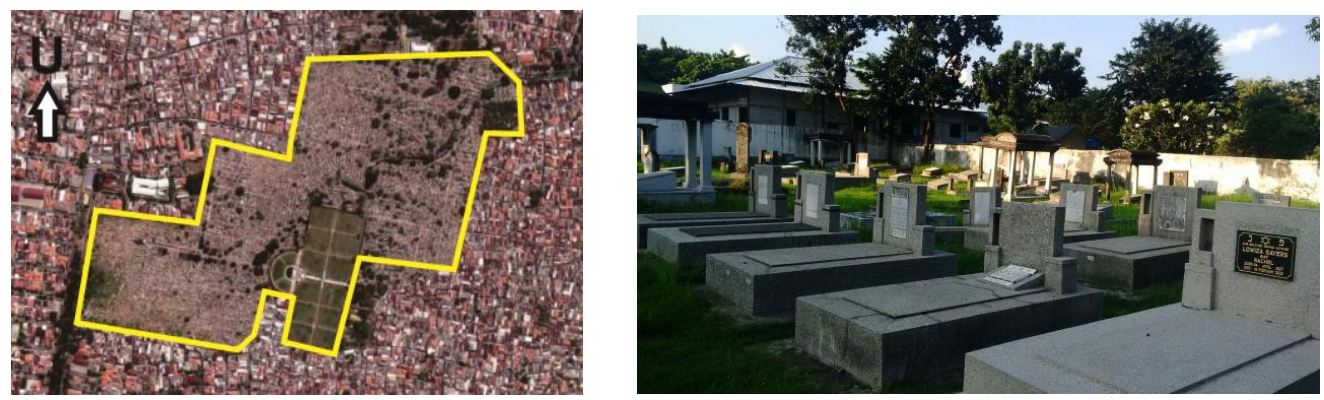

Gambar 8. Keadaan makam Kembang Kuning pada 2019 (kiri) dan Bentuk makamnya yang lebih sederhana dan seragam.

(Sumber: maps.google.com dan liputan6.com)

Makam-makam di permakaman Kembang Kuning memiliki bentuk dan hiasan yang lebih sederhana dan seragam dibanding makam Peneleh (Gambar 8). Permakaman Kembang Kuning saat ini dimanfaatkan sebagai permakaman untuk orang Kristen dan terdapat ereveld, yakni permakaman yang diperuntukan bagi tentara dan tawanan Belanda yang meninggal pada zaman pendudukan Jepang dan perang kemerdekaan.

Pemerintah kolonial Belanda memainkan peran penting dalam perkembangan kota Surabaya sejak kota tersebut jatuh ke tangan VOC pada tahun 1743. Tata kota Surabaya pada masa kolonial terbagi menjadi kawasan perdagangan dan jasa, kawasan hunian, kawasan pemerintahan, kawasan pertahanan dan kawasan. Di samping itu, Surabaya juga memiliki kawasan pendukung kota yang di dalamnya terdapat fasilitas pendidikan, kesehatan, taman publik, transportasi, dan pertahanan. Pemerintah kolonial Belanda sebagai penguasa kota memiliki kekuasaan untuk mengelompokan tempat tinggal penduduk pribumi, Timur Asing, dan Eropa. Permukiman orang-orang Tionghoa dikelompokkan di sepanjang timur Kali Mas dan Jalan Kembang Jepun. Sementara permukiman orang Arab dikelompokan di sekitar Masjid Ampel. Kemudian di sebelah selatannya, terdapat kota pribumi dengan alunalun sebagai pusat kota yang dikelilingi rumah pangeran, pasar, dan masjid. Namun karena adanya pembangunan benteng keliling Surabaya, maka permukiman pribumi tersebar di sekitar Surabaya. Sementara itu, orang-orang Eropa memiliki permukiman di sisi barat Jembatan Merah yang diberi tembok pelindung.

Pada abad ke 19, orang-orang Belanda mulai membangun tempat tinggal dan fasilitas lain ke selatan ke daerah Tunjungan. Banyaknya orang yang datang untuk menetap di kota Surabaya berdampak pada terjadinya perubahan fungsi lahan yang biasanya sulit dikendalikan. Pemerintah kota Surabaya kemudian berusaha mengendalikan penggunaan lahan untuk memenuhi keperluan 
mereka. Sebagai contoh adalah penetapan kawasan pinggiran kota seperti Ketabang, Bagong, Kedunganyar, Kupang dan Darmo pada tahun 1920 sebagai sebagai pemekaran kota (Von Faber, 1934, hlm. 1934). Kemudian pemerintah kota menggeser kawasan pemerintahan kolonial dari Jembatan Merah ke kaw-asan Tembaan dan Simpang yang berada di sebelah selatan kawasan pemerintahan yang lama. Kemudian wilayah Jembatan Merah dan Tunjungan menjadi kawasan perdagangan wilayah Ngagel dijadikan kawasan industri (Widodo, 2002, hlm. 406).

Di samping memiliki kekuasaan untuk mengatur permukiman, pemerintah kolonial juga memiliki kekuassaan untuk mengatur permakaman penduduk di Surabaya. Hal tersebut terlihat pada pengelompokan permakaman berdasarkan etnis yang diterapkan pemerintah kolonial. Pemerintah kolonial menetapkan Krembangan, kemudian Peneleh dan terakhir Kembang Kuning sebagai permakaman untuk orang-orang Eropa dan penganut agama Kristen dari kalangan Tionghoa atau pribumi. Sementara itu, permakaman orang Tionghoa berada di Tunjungan. Namun karena pemerintah kolonial menjadikan Tunjungan sebagai kawasan perdagangan dan jasa, maka permakaman orangorang Tionghoa menggeser sendiri letak permakamannya ke daerah Kupang di selatan Tunjungan. Sementara itu, permakaman pribumi tersebar ke beberapa penjuru kota dan pada umumnya setiap perkampungan pribumi memiliki permakaman sendiri.

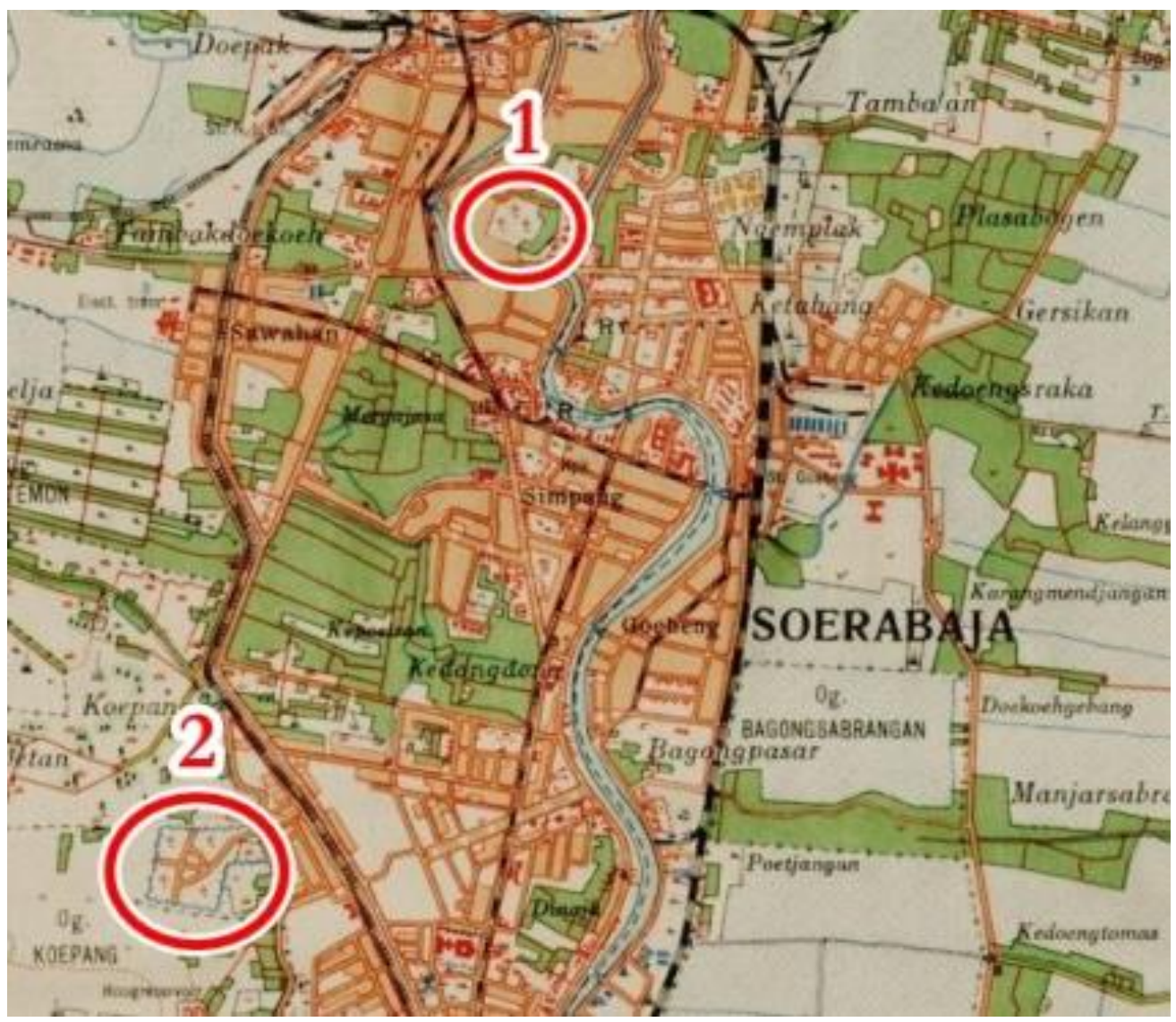

Gambar 9. Letak permakaman Belanda Peneleh (1) dan

Kembang Kuning (2) pada peta tahun 1925.

(Sumber: maps.library.leiden.edu) 
Pergeseran permakaman Belanda di Surabaya dimulai ketika gereja melarang permakaman Belanda yang berada di sekitar halaman gereja pada akhir abad ke-18. Larangan tersebut disebabkan karena dikhawatirkan timbulnya wabah penyakit dari jenasah yang baru saja dikuburkan. Wabah penyakit akan semakin mudah menular karena orang-orang setiap minggunya mendatangi gereja, apalagi letak gereja berada di tengah kota. Pemerintah kolonial menggeser lahan permakamannya ke Krembangan yang berada di sebelah barat kota. Berikutnya karena permakaman Krembangan mulai penuh dan keadaan tanahnya tidak sesuai untuk permakaman, pemerintah kolonial menggeser permakaman ke Peneleh. Pertimbangan Peneleh sebagai lokasi permakaman adalah karena pemerintah kolonial memfokuskan pembangunan kota Surabaya di sisi barat Kali Mas. Sementara letak Peneleh berada di timur Kali Mas sehingga keberadaan permakaman Belanda di Peneleh tidak akan menggangu pengembangan kota Surabaya dan bisa dilakukan perluasan. Keberadaan ossuarium yang ada di dalam permakaman Peneleh menunjukan bahwa angka permintaan lahan permakaman yang ada cukup tinggi namun tidak diimbangi dengan ketersediaan lahan.

Keterbatasan lahan tersebut disebabkan oleh munculnya perkampungan baru di sekitar permakaman sebagai hasil dari urbanisasi yang terjadi di Surabaya pada akhir abad ke-19. Karena lahan terbatas dan sementara itu ada kebutuhan lahan makam yang harus dipenuhi, maka makam-makam yang lama digali kembali untuk makam baru, sementara tulang belulang dari makam lama ditampung di ossuarium. Selain ossuarium, bukti lain tingginya permintaan lahan makam adalah adanya penguburan jenis huurkelders dan grafkelder, dimana dalam satu kuburan bisa diisi oleh lebih dari satu jenasah. Ketika pemerintah kota Surabaya mengembangkan kota Surabaya ke kawasan Darmo di selatan kota pada awal abad 20, pemerintah kota akhirnya membuka permakaman di Kembang Kuning yang dekat dengan kawasan Darmo. Dengan demikian letak permakaman Belanda akhirnya bergeser ke Kembang Kuning (Gambar 9). Letak permakaman Kembang Kuning yang dekat dengan kawasan Darmo diharapkan meningkatkan aksesbilitas pengantar jenasah dan peziarah. Pergeseran permakaman Belanda yang terjadi di Surabaya dipicu oleh beberapa faktor. Faktor yang pertama adalah kesehatan. Hal tersebut terjadi ketika pemerintah kolonial menggeser permakaman Belanda dari sekitar halaman gereja ke Krembangan. Faktor tersebut dipengaruhi oleh munculnya wabah penyakit di Eropa pada abad ke-18. Pada saat itu, muncul wabah penyakit yang menyebabkan banyak korban jiwa yang jatuh. Jenasah-jenasah yang meninggal akibat wabah tersebut akhirnya dikubur pada kuburan massal yang digali tidak terlalu dalam. Sisa-sisa jenasah yang membusuk akhirnya membuat udara di lingkungan sekitar kuburan menjadi tidak sehat dan banyak orang yang terjangkit penyakit. Hal tersebut tentu akan mengancam kesehatan masyarakat sekitar, apalagi letak gereja di Surabaya berada di tengah-tengah permukiman orang Eropa.

Faktor kedua adalah keadaan tanah permakaman yang tidak memungkinkan lagi untuk dilakukan perluasan. Hal tersebut terjadi ketika pemerintah kolonial menggeser permakaman dari Krembangan ke Peneleh. Pada awalnya, pemerintah kolonial memilih Krembangan sebagai letak permakaman 
dengan pertimbangan bahwa tempat tersebut masih jarang penduduknya, sehingga lahan permakaman nantinya dapat diperluas dan upaya pemekaran kota tidak terganggu. Namun ternyata tekstur tanah di Krembangan tidak mendukung untuk kegiatan permakaman karena tanahnya sering tergenang. Hal tersebut tentu tidak sesuai dengan kondisi tanah permakaman yang ideal seperti yang diuraikan oleh Poldevaart dalam majalah Locale Techniek edisi Oktober 1933. Poldevaart menjelaskan bahwa kriteria tanah yang ideal untuk lokasi permakaman adalah air harus mampu merembes ke dalam tanah, jenis tanahnya bukan tanah lempung atau padas agar mudah digali, dan drainasenya bagus. Apabila tanah sering tergenang, maka hal tersebut akan menyulitkan dalam proses penggalian tanah. Ketika lahan permakaman yang ada tidak memungkinkan lagi untuk dipakai permakaman, sementara masih ada kebutuhan pada tempat permakaman, maka jalan keluar yang dilakukan oleh pemerintah kolonial adalah dengan menggeser permakaman ke lokasi yang baru.

Faktor ketiga adalah beralih fungsinya lahan di sekitar permakaman menjadi permukiman. Faktor ini terjadi ketika pemerintah kolonial menggeser permakaman dari Peneleh ke Kembang Kuning. Sejalan dengan perkembangan kota Surabaya sebagai pusat pemerintahan dan perekonomian di Jawa Timur, jumlah penduduk semakin banyak. Wilayah yang semula masih jarang penduduk akhirnya menjadi permukiman, contohnya adalah Peneleh. Pemerintah kolonial memilih permakaman di Peneleh dengan perkiraan bahwa dibukanya permakaman di tempat tersebut tidak menghambat pemekaran kota Surabaya, dimana pemerintah kolonial lebih banyak membangun fasilitas di sebelah barat Kali Mas dibanding di sebelah timur Kali Mas. Di samping itu, pemerintah kolonial juga dapat memperluas permakaman Peneleh bila permakaman mulai penuh. Namun pada kenyataanya, sebelum lahan permakaman di Peneleh sudah penuh, lingkungan di sekitar permakaman sudah terlanjur berubah menjadi permukiman. Dengan demikian permakaman yang ada di Peneleh sulit untuk diperluas. Untuk memenuhi kebutuhan tempat permakaman, pemerintah kolonial akhirnya menggeser permakaman ke tempat yang baru di Kembang Kuning. Wilayah tersebut dipilih karena letaknya tidak terlalu jauh dari wilayah Darmo yang merupakan wilayah pemekaran kota. Walau setiap tahap pergeseran memiliki faktor yang berbeda-beda, namun pada dasarnya, semua tahap pergeseran permakaman Belanda di Surabaya dipengaruhi oleh satu faktor, yakni semakin penuhnya lahan permakaman.

\section{KESIMPULAN}

Setiap orang pasti akan meninggal dan karena itu permakaman sebagai tempat mengubur jasad orang yang sudah meninggal menjadi kebutuhan yang mutlak di setiap tempat, terutama pada tempat yang masyarakatnya mengenal tradisi penguburan. Kebutuhan permakaman untuk orang Eropa di Surabaya disediakan oleh pemerintah kolonial. Pemerintah kolonial dengan kekuasaanya, dapat memilih dan menentukan lokasi permakaman untuk orang Belanda yang sesuai dengan kebutuhan. Setidaknya pernah ada empat permakaman Belanda dengan letak yang berbeda, yakni di halaman gereja di dekat Jembatan Merah, 
Krembangan, Peneleh, dan Kembang Kuning. Keempat permakaman tersebut dibuka dalam kurun waktu yang berlainan, dari abad ke-18 hingga awal abad ke-20. Sepanjang kurun waktu tersebut, dua permakaman, yakni di Jembatan Merah dan Krembangan dibongkar karena sudah tidak layak untuk permakaman dan makam-makam dari permakaman tersebut dipindah ke tempat lain. Pergeseran letak permakaman Belanda di Surabaya dipicu oleh tiga faktor, yakni faktor kesehatan, keadaan tanah permakaman yang tidak mendukung, dan beralihfungsinya lahan di sekitar permakaman menjadi permukiman. 


\section{DAFTAR PUSTAKA}

Ambary, Hasan Muarif. (1998). Menemukan Peradaban, Jejak Arkeologis dan Historis Islam Indonesia. Jakarta: Logos Wacana Ilmu.

Anshcuetz, Kurt.F. Wilshusen, Richard. H dan Sheick, Cherie.L. (2001). An Archaeology of The Landscape: Prespective and Directions. Journal of Archaeology Research, Vol. 9, No.2: $157-211$.

Balai Arkeologi Yogyakarta. (1998/1999). “Keletakan dan Bentuk Makam-Makam Belanda pada Kota-kota Pantai (Tahap I). Departemen Pendididikan dan Kebudayaan.

Branto, Nicole. (2009). “Landscape Approaches in Historical Archaeology: The Archaeology of Places" dalam Majewski, Teresita dan Gaimster, David. International Handbook of Historical Archaeology, 51-65. New York: Springer.

Francaviglia, Richard V. (1971). The Cemetery as an Evolving Cultural Landscape. Annals of the Association of American Geographers, Vol. 61, No. 3: 501-509.

Kerrigan. Michael. (2017). Sejarah Kematian ; Tradisi Penguburan dan Ritus-ritus Pemakaman dari Zaman Kuno sampai Zaman Modern. Jakarta : Elex Media Computindo.

Leushuis. Emile. (2014). Panduan Jelajah Kota-kota Pusaka di Indonesia. Yogyakarta : Penerbit Ombak.

Mahendrani, Cahya Ratna. (2013). Nisan Makam Belanda Peneleh Surabaya ; Kajian Tentang Bentuk dan Ragam Hias. (Skripsi). Yogyakarta : Fakultas Ilmu Budaya Universitas Gajah Mada.

Mytum, Harold. (1989). Public Health and Private Sentiment: The Development of Cemetery Architecture and Funerary Monuments from the Eighteenth Century Onwards. World Archaeology, Vol. 21, No. 2: 283 - 297.

Nurhadi. (1987). Arkeologi Kubur Islam di Indonesia. Jakarta: Pusat Penelitian Arkeologi Nasional.

Poldervaart, A. (1933). " De Nieuwe Europeesche Begrafplaats te Bandoeng " dalam Locale Techniek no.4 bulan Oktober 1933.

Shinta, Desril Riva. (2010). “Ragam Hias Bong Cina di Kompleks Ku Tiong Laya Kota Cirebon" dalam Wahyudi, Wanny Rahadrjo (ed), Dari Masa Lalu Ke Masa Kini, 128-144. Sumedang: Penerbit Alqaprint.

Suratminto, Lilie. (2008). Makna Sosio-Historis Batu Nisan VOC di Batavia. Jakarta: Wedatama Widya Sastra.

Tantomi, Ade Faizel. (2013). Bentuk-Bentuk Nisan Belanda di Kerkhof Purworejo. (Skripsi). Yogyakarta: Fakultas Ilmu Budaya Universitas Gajah Mada. 
Widodo, Dukut Imam. (2002). Soerabaia Tempo Doeloe. Surabaya: Dinas Pariwisata.

Von Faber, G.H. (1932). Oud Soerabia; De Geschiedenis van Indies Eerste Koopstad van de Oudste Tijden tot de Instelling van Den Gemeenteraad. Surabaya: Gementee Soerabaia.

Von Faber, G.H. (1932). Nieuw Soerabia ; De Geschiedenis van Indies Voornaamste Koopstad in De Eerste Kwareeuw Sedert Hare Instelling 1906-1931. Surabaya: N.V. Boekhandel en Drukkerij H.van Ingen. 